UDC: 616-013.395:591.81:591.3:616.832-002-056.3-092.9

(3) Tsymbaliuk V. I. ${ }^{1}$, Velychko O. M. ${ }^{1}$, Pichkur O. L. ${ }^{1}$, Verbovska S. A. ${ }^{1}$, Pichkur L. D. ${ }^{1}$, Shuvalova N. S. ${ }^{2}$

${ }^{1}$ O. P. Romodanov State Institute of Neurosurgery NAMS Ukraine, Kyiv, Ukraine

${ }^{2}$ State Institute of Genetic and Regenerative Medicine NAMS Ukraine, Kyiv, Ukraine

e-mail: verbovskaya-svetlana@ukr.net

\title{
EFFECTS OF HUMAN WHARTON'S JELLY-DERIVED MESENCHYMAL STEM CELLS AND INTERLEUKIN-10 ON BEHAVIOURAL RESPONSES OF RATS WITH EXPERIMENTAL ALLERGIC ENCEPHALOMYELITIS
}

\section{ABSTRACT}

On the rat model of experimental allergic encephalomyelitis (EAE), as analogue of multiple sclerosis of human, we studied the effect of Wharton's jelly-derived mesenchymal stem cells and interleukin-10 on the functional parameters of the CNS.

MATERIALS AND METHODS. EAE was induced with spinal cord homogenate of rats with complete Freund's adjuvant. MSCs were isolated by the explants technique from Wharton's jelly of the human umbilical cord and cultured up to two passages. Recombinant IL-10 was administered intravenously on the day 10 after induction of EAE and subocipitally on the day 17 at a dose of $0.2 \mathrm{mg}$ per animal. Cell transplantation performed subocipitally on the day 17 at a dose of $10^{6}$ cells per animal. Behavioral reactions studied in the "open field» test three times: on the day 12 , 15 and 24 after the induction of EAE.

RESULTS. Induced EAE results in significant changes in adaptive behavior of rats on the $12^{\text {th }}$ day as suppression of orienting-exploratory and activation of emotional activity. The application of MSCS and IL-10 has normalized the rates of cognitive activities (orienting-exploratory activity) and emotional sphere (the level of fear, anxiety).

CONCLUSION. Combined treatment of induced EAE in rats with interleukin-10 and human Wharton's jelly-derived mesenchymal stem cells is effective at correction of behavioral responses of animals.

KEYWORDS: experimental allergic encephalomyelitis; Wharton's jelly-derived mesenchymal stem cells; interleukin-10; "open field» test

Any progress in the treatment of inflammatory and degenerative lesions of human CNS is associated with the development of cellular technology. Today the possibility of influence on destructive autoimmunity and neurotrophic processes via cell progenitors of various origins (neural stem cells of fetal brain, hematopoietic stem cells) has been successfully studied. But it is much more difficult to influence on the degenerative-dystrophic processes. In addition, often application of cell progenitors has bioethical limitations. Recently, the application of mesenchymal stem cells (MSCs) has become widespread. There were published data on the identification and successful isolation of MSCs from almost all tissues of the body $[1,2]$, but the main attention is paid to such cell sources as bone marrow and adipose tissue $[3,4,5]$. Despite the common name, MSCs from different sources have significant differences in the availability and safety.

Wharton's jelly of the human umbilical cord, unlike bone marrow and adipose tissue, contains cells preserved from the earliest stages of embryogenesis. The umbilical cord as a derivative of the yolk sac and allantois contains a primitive form of extraembryonic mesenchyme mucosal connective tissue (Wharton's jelly) [6], which by its cellular composition and structure occupies an intermediate position between embryonic mesenchyme and adult connective tissue [7]. Fibroblast cells dominate in its cellular composition. They actively synthesize glycosaminoglycans, and, according to some authors, do not retain 
multipotent (unlike bone marrow and adipose tissue, which are adult MSCs) but even pluripotent stem potential [8]. There are data about the possibility of their expression of embryonic markers Oct4 and Tra-160, Tra-1-81, SSEA-1, SSEA-4 [9]. They are slightly different from the mature immunophenotype, which opens additional opportunities for allotransplantation [10, 11]. Introduction of cells from the umbilical cord to the culture does not create moral and ethical conflict; the procedure for obtaining MSCs from umbilical cord is simple. Experiments with animals after immunosuppression proved that intravenous or subcutaneous injection of these cells does not lead to their rejection or critical negative impact. Experiments on animals without immunosuppression showed that at least single transplantation of xenogeneic cells from Wharton's jelly of umbilical cord is possible without their immediate rejection. Literature data confirm more pronounced immunosuppressive properties of umbilical cord MSCs compared to similar cells from other sources. This fact indicates their promising use in regenerative medicine [12]. MSCs from Wharton's jelly proliferate in vitro well, have unique properties (migration into the white matter of the spinal cord after intraventricular injections, transdifferentiation into cells of ectodermal origin, existence of systemic and local immunomodulating influence due to rapid increase of regulatory lymphocytes and reduction in the number of activated antigen presenting cells). Along with that MSCs are able to stimulate the synthesis and self synthesize a number of anti-inflammatory cytokines. These properties can be extremely important for the correction of autoimmune conditions.

However, it is believed that damaging inflammation factors negatively affect the live activity of introduced MSCs, possibly creating limitations for full implementation of their therapeutic potential [13]. Therefore, there is a promising idea of simultaneous application of MSCs and reduction of inflammation. $I L-10$ is considered to be one of the key anti-inflammatory cytokines [14]. Some studies have shown the key role of $I L-10$ in the prevention and treatment of autoimmune conditions and autoimmune diseases of the CNS $([15,16,17]$.

We have assumed that simultaneous application of MSCs and IL-10 can mutually reinforce their therapeutic effect. Taking into account the unique characteristics and properties of MSCs from Wharton's jelly, we conducted a comprehensive experimental study of efficiency of application MSCs in focal lesions of the central nervous system of rats with simulated experimental allergic encephalomyelitis (EAE) in combination with the introduction of $I L-10$, to create a new immunogenetic status and correct motor disorders of experimental animals. There was also carried out an experimental study of the effect of a new treatment on behavioral responses of rats.

Evaluation of the functional state of the central nervous system of animals is a necessary part in the experiment with the study of EAE negative impact on the nervous system. One of the methods of assessing the state of the nervous system is the study of behavioral reactions based on the study of orienting and research reaction of animals. Behavioral responses of rats are investigated in the test "open field", which is the most common and widely used to study the behavior of rodents in stressful conditions, allows evaluating of the severity and dynamics of individual behavioral elements, motor activity, and strategy of exploratory memorizing of situational stimuli, the level of emotional and behavioral reactivity of animals.

The purpose of the study was to investigate the effect of mesenchymal stem cells from human Wharton's jelly and interleukin-10 on the functional state of CNS of rats with experimental allergic encephalomyelitis.

\section{MATERIALS AND METHODS}

The studies were conducted at the Department of Experimental Neurosurgery and Clinical Pharmacology of A. P. Romodanov State Institute of Neurosurgery NAMS of Ukraine (Certificate of attestation №PT-145/09, issued 14.05.2010, valid 13.05.2015).
The study was carried out on 43 white outbred female rats weighing 200-230 g from the vivarium of A. P. Romodanov State Institute of Neurosurgery NAMS of Ukraine. They were kept under standard conditions and diet with free access to water.

All experimental procedures on rats were performed in accordance with international rules and norms of European Communities Council Directives of 24 November1986, 86/609/EEC and according to the principles of the "European Convention for the Protection of vertebrate animals used for experimental and scientific purposes" (Strasbourg, 1986) and the Law of Ukraine №3447-IV "On protection of animals from cruelty" of 21.20.2006 [18, 19].

EAE was induced with spinal cord homogenate of rats with complete Freund's adjuvant (Sigma, USA) according to standard protocol [20] with a change in the ratio of components of encephalitogeneic mixture (the ratio of adjuvant to brain tissue 1.6:1), which allowed to receive chronic non-severe relapsing course of EAE [21]. Chronic relapsing form of EAE allows more detailed study of the influence of factors on the course of demyelinating process, and avoids mortality of experimental animals, which according to some researchers in acute EAE reaches 30-60\% [21]. Encephalitogeneic mixture was administered in rats' limb pads according to $[20,21]$ at a rate of $50 \mathrm{mg}$ encephalitogeneic mixture for each animal.

Distribution in experimental groups is presented in Table 1.

Our previous studies revealed that most clinical manifestations in animals with EAE $[21,22]$ were observed on $17^{\text {th }}$ day after induction of EAE. Therefore we have allocated a group of animals, in which on the $10^{\text {th }}$ day we injected $I L-10$ intravenously for the anti-inflammatory effect. At the peak of clinical manifestations on the $16^{\text {th }}$ day the animals were injected with MSCs expecting to assess anti-inflammatory effects and ability of MSCs to prevent demyelination processes and accelerate remyelination of the CNS at the morphological level.

Rats with EAE were treated with intravenous or suboccipital introduction of various combinations of $I L-10$ and MSCs. Recombinant human IL-10 was received at the Institute of Molecular Biology and Genetics NAS of Ukraine and kindly provided for the experiment.

MSCs were isolated by the method of explants from Wharton's jelly of the human umbilical cord. Umbilical cords, obtained from healthy parturient women during normal deliveries, were provided by Kyiv municipal maternity hospital No. 5. The women signed an information letter of agreement to provide material for scientific research.

The material was treated no later than 5 hours after the birth. Delivery to the laboratory was held in the DMEM environment with 1000 units/ $\mathrm{ml}$ penicillin (Arterium, Ukraine) and $1 \mathrm{mg} / \mathrm{ml}$ streptomycin (Arterium, Ukraine). The umbilical cord was washed of the blood, placed in DMEM medium with antibiotics $1000 \mathrm{U} / \mathrm{ml}$ penicillin and $1 \mathrm{mg} / \mathrm{ml}$ streptomycin and antimycotics Amphotericin $50 \mathrm{U} / \mathrm{ml}$ (Kievmedpreparat, Ukraine) for 30 minutes. All manipulations were carried out under sterile conditions.

Table 1. Experimental groups of animals

\begin{tabular}{|c|c|c|}
\hline $\begin{array}{l}\text { GROUP } \\
\text { NO. }\end{array}$ & $\begin{array}{l}\text { NUMBER OF } \\
\text { ANIMALS }\end{array}$ & TREATMENT \\
\hline 1 & 8 & Control group, untreated EAE \\
\hline 2 & 8 & $\begin{array}{l}\text { Treatment of EAE with MSCs }\left(10^{6} \text { cells/ }\right. \\
\text { animal subocipitally) on the day } 17\end{array}$ \\
\hline 3 & 8 & $\begin{array}{l}\text { Treatment of EAE with IL- } 10(0.2 \mu \mathrm{g} / \\
\text { animal intravenuously) on the day } 10 \text {, } \\
\text { IL-10 subocipitally on the day } 17 .\end{array}$ \\
\hline 4 & 7 & $\begin{array}{l}\text { Treatment of EAE with IL-10 (0.2 } \mu \mathrm{g} / \\
\text { animal intravenuously) on the day } \\
10 \text { and IL- } 10+\text { MSCs subocipitally } \\
\text { on the day } 17\end{array}$ \\
\hline 5 & 12 & Intact rats \\
\hline
\end{tabular}




\begin{tabular}{|c|c|c|c|}
\hline ACTIVITY & INDEX & INTACT, N=12 & EAE, $N=8$ \\
\hline \multirow{2}{*}{$\begin{array}{l}\text { Horizontal } \\
\text { activity }\end{array}$} & LP & $1.50 \pm 0.19$ & $1.53 \pm 0.22$ \\
\hline & $\mathrm{n} 1$ & $7.25 \pm 1.21$ & $9.75 \pm 2.03$ \\
\hline \multirow{2}{*}{$\begin{array}{l}\text { Central } \\
\text { quadrants }\end{array}$} & $\mathrm{n} 2$ & $6.17 \pm 1.20$ & $4.75 \pm 1.60$ \\
\hline & ns & $13.42 \pm 1.90$ & $14.50 \pm 2.72$ \\
\hline \multirow{4}{*}{$\begin{array}{l}\text { Horizontal } \\
\text { activity } \\
\text { Peripherial } \\
\text { quadrants }\end{array}$} & LP & $8.07 \pm 1.16$ & $5.53 \pm 0.95$ \\
\hline & $\mathrm{n} 1$ & $67.75 \pm 5.40$ & $\begin{array}{c}39.88 \pm 4.19 \\
p<0.0015^{\star}\end{array}$ \\
\hline & $\mathrm{n} 2$ & $50.25 \pm 4.04$ & $\begin{array}{c}26.50 \pm 5.02 \\
p<0.004^{*}\end{array}$ \\
\hline & ns & $118.00 \pm 7.31$ & $\begin{array}{c}66.38 \pm 8.73 \\
p<0.0002^{\star}\end{array}$ \\
\hline \multirow{10}{*}{$\begin{array}{l}\text { Vertical } \\
\text { activity }\end{array}$} & LP & $44.74 \pm 10.13$ & $\begin{array}{c}10.39 \pm 1.98 \\
p<0.0001^{*}\end{array}$ \\
\hline & $\mathrm{n} 1$ & $14.58 \pm 1.76$ & $15.63 \pm 2.18$ \\
\hline & $\mathrm{n} 2$ & $16.75 \pm 1.44$ & $14.38 \pm 2.42$ \\
\hline & ns & $31.33 \pm 2.74$ & $30.00 \pm 3.61$ \\
\hline & $\mathrm{T1}$ & $41.34 \pm 5.38$ & $43.46 \pm 7.29$ \\
\hline & $\mathrm{T} 2$ & $51.88 \pm 5.13$ & $44.36 \pm 10.21$ \\
\hline & Ts & $93.22 \pm 8.83$ & $87.82 \pm 13.10$ \\
\hline & $\mathrm{t} 1$ & $2.83 \pm 0.21$ & $2.72 \pm 0.15$ \\
\hline & t2 & $3.17 \pm 0.22$ & $2.97 \pm 0.23$ \\
\hline & ts & $2.99 \pm 0.12$ & $2.91 \pm 0.17$ \\
\hline \multirow{10}{*}{$\begin{array}{l}\text { Emotional } \\
\text { activity } \\
\text { (grooming) }\end{array}$} & LP & $102.23 \pm 13.21$ & $100.30 \pm 32.07$ \\
\hline & $\mathrm{n} 1$ & $3.67 \pm 0.74$ & $3.13 \pm 0.64$ \\
\hline & $\mathrm{n} 2$ & $3.42 \pm 0.62$ & $2.75 \pm 0.49$ \\
\hline & ns & $7.08 \pm 0.99$ & $5.88 \pm 0.79$ \\
\hline & $\mathrm{T} 1$ & $15.54 \pm 2.53$ & $16.70 \pm 3.44$ \\
\hline & $\mathrm{T} 2$ & $25.45 \pm 6.73$ & $29.95 \pm 7.86$ \\
\hline & Ts & $40.99 \pm 8.08$ & $46.65 \pm 7.65$ \\
\hline & $\mathrm{t1}$ & $4.92 \pm 1.00$ & $5.05 \pm 0.93$ \\
\hline & t2 & $10.41 \pm 3.20$ & $9.21 \pm 2.11$ \\
\hline & ts & $7.08 \pm 1.82$ & $8.18 \pm 1.32$ \\
\hline $\begin{array}{l}\text { Emotional } \\
\text { activity } \\
\text { (boluses) }\end{array}$ & $n$ & $0 \pm 0$ & $0.63 \pm 0.32$ \\
\hline \multirow{10}{*}{$\begin{array}{l}\text { Exploratory } \\
\text { activity } \\
\text { (holes) }\end{array}$} & LP & $202.41 \pm 47.44$ & $\begin{array}{c}398.50 \pm 77.51 \\
p<0.031^{*}\end{array}$ \\
\hline & $\mathrm{n} 1$ & $1.83 \pm 0.39$ & $0.63 \pm 0.26$ \\
\hline & $\mathrm{n} 2$ & $1.67 \pm 0.53$ & $1.13 \pm 0.58$ \\
\hline & ns & $3.50 \pm 0.68$ & $1.75 \pm 0.77$ \\
\hline & $\mathrm{T} 1$ & $4.91 \pm 1.08$ & $1.70 \pm 0.70$ \\
\hline & $\mathrm{T} 2$ & $4.19 \pm 1.30$ & $2.05 \pm 1.06$ \\
\hline & Ts & $9.09 \pm 1.67$ & $\begin{array}{c}3.75 \pm 1.64 \\
p<0.047^{*}\end{array}$ \\
\hline & $\mathrm{t} 1$ & $2.01 \pm 0.39$ & $1.39 \pm 0.55$ \\
\hline & t2 & $1.86 \pm 0.49$ & $0.69 \pm 0.34$ \\
\hline & ts & $2.80 \pm 0.30$ & $\begin{array}{c}1.09 \pm 0.42 \\
p<0.004^{*}\end{array}$ \\
\hline
\end{tabular}

The vessels, one vein and two arteries, were removed from the umbilical cord and Wharton's jelly was separated. Than it was minced with scissors to the least possible size of $0.1-0.5 \mathrm{~cm}$ and placed in 75 $\mathrm{cm} 2$ culture vial (Grenier Bio-One, Austria) with growth medium a-MEM, 2 mM L-glutamine (BioWest, Spain), antibiotics $100 \mathrm{U} / \mathrm{ml}$ benzylpenicillin (Arterium, Ukraine), $100 \mu \mathrm{g} / \mathrm{ml}$ streptomycin (Arterium, Ukraine) and 10\% fetal calf serum (HyClone, USA). Cultivation was carried out in standard conditions in a $\mathrm{CO}_{2}$ incubator $\left(37^{\circ} \mathrm{C}, 5 \% \mathrm{CO}_{2}\right.$, humidified atmosphere). After 7-14 days attached individual cells and clones could be seen in culture bottles. The resulting culture was considered to be a zero passage and cultured in the above conditions. Reaching a monolayer with $70 \%$ confluency cells were passed using $0.02 \%$ Versen solution and $0.25 \%$ trypsin in 1:1 ratio. Cells of passage 2 were used for injection into the test animals. The cells were characterized by the morphology and surface markers. The number of cells was determined with Goryaev's chamber.

To assess the state of cultures we used inverted microscope Leica DMIL (Leica, Germany). FACS-analysis of MSCs surface markers CD105, CD90, CD73 expression (Becton Dickinson, USA) was performed on the BD FACSAria cell sorter using the BD FACSDiva software (Becton Dickinson, USA).

Behavioral responses of rats of groups 1, 2, 3 and 4 were studied by the open field test three times, and animals from the group 5 - once. The first test was performed in experimental rats of groups 1, 2, 3 and 4 on the $12^{\text {th }}$ day after the induction of EAE. The second test was performed in the animal of groups 1 and 2 on the $15^{\text {th }}$ day after induction of EAE, in rats of groups 3 and 4 on the $15^{\text {th }}$ day after induction of EAE ( $7^{\text {th }}$ day after the intravenous administration of $I L-10)$. The third test was performed in rats of group 1 on the $24^{\text {th }}$ day after induction of EAE, in rats of group 2 on the $24^{\text {th }}$ day after induction of EAE ( $7^{\text {th }}$ day after the suboccipital introduction of MSCs), in rats of group 3 on the $24^{\text {th }}$ day after induction of EAE (15 day after the intravenous administration of $I L-10$ and the $7^{\text {th }}$ day after suboccipital introduction of $I L-10$ ), in the rats of group 4 on the $24^{\text {th }}$ day after induction of EAE ( $15^{\text {th }}$ day after intravenous administration of $I L-10$ and the $7^{\text {th }}$ day after suboccipital introducing of $I L-10$ and MSCs).

Adaptive behavior of animals was evaluated by the open field test for 10 minutes (for the first 5 minutes, the second 5 minutes and 10 minutes of research - the total figure) in terms of horizontal (crossing of the central and peripheral squares) and vertical locomotor activity (standing up on back paws - vertical rack), exploratory activity (looking into the burrows), emotional activity (grooming and defecation (number of boluses)). Using the software and computer complex on the study

4

Table 2. Comparison of behavioral responses ofintact rats and rats on the $12^{\text {th }}$ day after the induction of $E A E$, first test $(M \pm m)$.

$\mathbf{\gamma}$ Note:

$L P$-latent period

$n 1$ - number of episodes during the first 5 minutes:

$n 2$ - number of episodes for the second 5 minutes;

ns - total number of episodes;

$T 1$ - the duration of the episodes during the first 5 minutes:

T2 - duration of episodes for the second 5 minutes;

TS - total duration of episodes;

t1- average duration of individual episodes during during the first 5 minutes;

t2- average duration of individual episodes during for the second 5 minutes;

ts - the average duration of individual episodes during 10 minutes of observations;

$p^{*}$ - probable differences when comparing the experimental groups. $p^{* *}$ - probable differences when comparing the experimental groups (EAE and $E A E+M S C s)$;

$p^{* * *}$ - probable differences when comparing the experimental groups (EAE and $E A E+(L-10)$;

$p^{* * * *}$ - probable differences when comparing the experimental groups (EAE and $E A E+I L-10+M S C S)$. 


\begin{tabular}{|c|c|c|c|c|c|c|}
\hline ACTIVITY & INDEX & $\begin{array}{c}\text { INTACT RATS, } \\
\mathrm{N}=12\end{array}$ & $\begin{array}{l}\text { EAE, } \\
\mathrm{N}=8\end{array}$ & $\begin{array}{c}\text { EAE+MSCS, } \\
\mathbf{N}=8\end{array}$ & $\begin{array}{c}\text { EAE+IL-10, } \\
\quad \mathrm{N}=7\end{array}$ & $\begin{array}{c}\text { EAE+IL-10 +MSCS, } \\
\mathrm{N}=4\end{array}$ \\
\hline \multirow{4}{*}{$\begin{array}{l}\text { Horizontal } \\
\text { activity } \\
\text { Central } \\
\text { quadrants }\end{array}$} & LP & $1.50 \pm 0.19$ & $1.16 \pm 0.07$ & $6.32 \pm 3.12 p<0.028^{* *}$ & $2.21 \pm 0.57 p<0.002^{* * *}$ & $\begin{array}{c}2.19 \pm 0.69 \\
p<0.028^{* \star * \star}\end{array}$ \\
\hline & $\mathrm{n} 1$ & $7.25 \pm 1.21$ & $14.38 \pm 3.83$ & $8.25 \pm 1.60$ & $9.29 \pm 2.65$ & $14.75 \pm 7.36$ \\
\hline & n2 & $6.17 \pm 1.20$ & $5.50 \pm 1.95$ & $4.00 \pm 1.41$ & $2.71 \pm 1.44$ & $27.50 \pm 17.88$ \\
\hline & ns & $13.42 \pm 1.9$ & $19.88 \pm 4.98$ & $12.25 \pm 2.33$ & $12.0 \pm 3.25$ & $42.25 \pm 25.1$ \\
\hline \multirow{2}{*}{$\begin{array}{l}\text { Horizontal } \\
\text { activity }\end{array}$} & $L p$ & $8.07 \pm 1.16$ & $9.59 \pm 6.05$ & $11.58 \pm 4.13 p<0.028^{* *}$ & $129.06 \pm 80.36$ & $10.45 \pm 3.63$ \\
\hline & $\mathrm{n} 1$ & $67.75 \pm 5.40$ & $60.88 \pm 10.54$ & $50.00 \pm 10.29$ & $51.14 \pm 14.73$ & $75.50 \pm 24.94$ \\
\hline \multirow{2}{*}{$\begin{array}{l}\text { Peripherial } \\
\text { quadrants }\end{array}$} & $\mathrm{n} 2$ & $50.25 \pm 4.04$ & $29.00 \pm 7.49$ & $24.63 \pm 5.11$ & $29.86 \pm 7.54$ & $54.25 \pm 18.10$ \\
\hline & ns & $118.00 \pm 7.31$ & $89.88 \pm 14.96$ & $74.63 \pm 12.94$ & $81.00 \pm 18.70$ & $129.75 \pm 39.80$ \\
\hline \multirow{10}{*}{$\begin{array}{l}\text { Vertical } \\
\text { activity }\end{array}$} & LP & $44.74 \pm 10.13$ & $42.10 \pm 12.15$ & $86.15 \pm 46.05$ & $97.14 \pm 55.96$ & $104.53 \pm 45.75$ \\
\hline & $\mathrm{n} 1$ & $14.58 \pm 1.76$ & $16.63 \pm 2.31$ & $12.63 \pm 2.99$ & $14.86 \pm 4.18$ & $13.50 \pm 4.86$ \\
\hline & $\mathrm{n} 2$ & $16.75 \pm 1.44$ & $10.63 \pm 2.50$ & $11.50 \pm 2.65$ & $12.57 \pm 3.18$ & $12.50 \pm 2.33$ \\
\hline & ns & $31.33 \pm 2.74$ & $27.25 \pm 4.42$ & $24.13 \pm 5.11$ & $27.43 \pm 7.15$ & $26.00 \pm 5.28$ \\
\hline & $\mathrm{T} 1$ & $41.34 \pm 5.38$ & $42.53 \pm 6.75$ & $35.51 \pm 9.57$ & $49.43 \pm 13.49$ & $34.89 \pm 12.63$ \\
\hline & $\mathrm{T} 2$ & $51.88 \pm 5.13$ & $37.96 \pm 10.02$ & $34.67 \pm 7.71$ & $61.41 \pm 13.46$ & $40.25 \pm 8.17$ \\
\hline & Ts & $93.22 \pm 8.83$ & $80.48 \pm 15.89$ & $70.18 \pm 15.60$ & $110.84 \pm 26.36$ & $75.13 \pm 15.19$ \\
\hline & $\mathrm{t} 1$ & $2.83 \pm 0.21$ & $2.51 \pm 0.21$ & $2.41 \pm 0.37$ & $2.80 \pm 0.67$ & $2.57 \pm 0.40$ \\
\hline & t2 & $3.17 \pm 0.22$ & $3.40 \pm 0.31$ & $3.20 \pm 0.27$ & $5.91 \pm 1.17 p<0.029^{* * *}$ & $3.19 \pm 0.30$ \\
\hline & ts & $2.99 \pm 0.12$ & $2.84 \pm 0.22$ & $3.02 \pm 0.21$ & $4.74 \pm 0.72 p<0.029^{\star \star *}$ & $2.91 \pm 0.36$ \\
\hline \multirow{10}{*}{$\begin{array}{l}\text { Emotional } \\
\text { activity } \\
\text { (grooming) }\end{array}$} & LP & $102.23 \pm 13.20$ & $60.62 \pm 11.72$ & $68.56 \pm 24.00$ & $92.23 \pm 41.05$ & $57.39 \pm 8.47$ \\
\hline & $\mathrm{n} 1$ & $3.67 \pm 0.74$ & $4.00 \pm 0.42$ & $4.63 \pm 0.73$ & $5.00 \pm 1.15$ & $5.00 \pm 1.22$ \\
\hline & n2 & $3.42 \pm 0.62$ & $4.00 \pm 1.00$ & $5.75 \pm 0.80$ & $3.43 \pm 0.95$ & $4.75 \pm 1.75$ \\
\hline & ns & $7.08 \pm 0.99$ & $8.00 \pm 0.91$ & $10.38 \pm 1.16$ & $8.43 \pm 1.34$ & $9.75 \pm 2.17$ \\
\hline & $\mathrm{T} 1$ & $15.54 \pm 2.53$ & $39.99 \pm 7.09$ & $40.08 \pm 9.76$ & $51.93 \pm 14.67$ & $33.40 \pm 9.39$ \\
\hline & $\mathrm{T} 2$ & $25.45 \pm 6.73$ & $32.63 \pm 11.52$ & $88.44 \pm 14.34 p<0.01^{* *}$ & $30.85 \pm 9.33$ & $47.51 \pm 20.3$ \\
\hline & Ts & $40.99 \pm 8.08$ & $72.62 \pm 9.98$ & $128.51 \pm 16.60 p<0.028^{\star *}$ & $82.78 \pm 8.68$ & $80.91 \pm 27.34$ \\
\hline & $\mathrm{t1}$ & $4.92 \pm 1.00$ & $10.22 \pm 1.59$ & $10.96 \pm 3.56$ & $9.39 \pm 3.01$ & $6.54 \pm 1.05$ \\
\hline & †2 & $10.41 \pm 3.20$ & $7.66 \pm 2.46$ & $16.58 \pm 3.23 p<0.005^{\star \star}$ & $9.10 \pm 2.74$ & $9.40 \pm 2.60$ \\
\hline & ts & $7.08 \pm 1.82$ & $9.20 \pm 1.08$ & $14.11 \pm 3.24$ & $12.01 \pm 2.48$ & $7.50 \pm 1.42$ \\
\hline $\begin{array}{l}\text { Emotional } \\
\text { activity } \\
\text { (boluses) }\end{array}$ & $\mathrm{n}$ & $0 \pm 0$ & $0.63 \pm 0.50$ & $0 \pm 0$ & $0 \pm 0$ & $0 \pm 0$ \\
\hline \multirow{10}{*}{$\begin{array}{l}\text { Exploratory } \\
\text { activity } \\
\text { (holes) }\end{array}$} & LP & $202.41 \pm 47.44$ & $479.81 \pm 65.74$ & $317.20 \pm 58.90$ & $448.35 \pm 93.80$ & $432.99 \pm 129.60$ \\
\hline & $\mathrm{n} 1$ & $1.83 \pm 0.39$ & $0.25 \pm 0.16$ & $1.00 \pm 0.38$ & $0.29 \pm 0.18$ & $0.50 \pm 0.50$ \\
\hline & n2 & $1.67 \pm 0.53$ & $0.38 \pm 0.18$ & $0.50 \pm 0.27$ & $0.14 \pm 0.14$ & $1.75 \pm 1.44$ \\
\hline & ns & $3.50 \pm 0.68$ & $0.63 \pm 0.18$ & $1.50 \pm 0.53$ & $0.43 \pm 0.20$ & $2.25 \pm 1.31$ \\
\hline & $\mathrm{T} 1$ & $4.91 \pm 1.08$ & $0.41 \pm 0.30$ & $1.57 \pm 0.70$ & $0.28 \pm 0.19$ & $1.19 \pm 1.19$ \\
\hline & $\mathrm{T} 2$ & $4.19 \pm 1.30$ & $0.59 \pm 0.31$ & $0.69 \pm 0.40$ & $0.46 \pm 0.46$ & $5.61 \pm 5.0$ \\
\hline & Ts & $9.09 \pm 1.67$ & $1.00 \pm 0.34$ & $2.26 \pm 0.95$ & $0.74 \pm 0.45$ & $6.81 \pm 4.68$ \\
\hline & $\mathrm{t1}$ & $2.01 \pm 0.39$ & $0.41 \pm 0.30$ & $0.91 \pm 0.32$ & $0.28 \pm 0.19$ & $0.60 \pm 0.60$ \\
\hline & t2 & $1.86 \pm 0.49$ & $0.59 \pm 0.31$ & $0.51 \pm 0.27$ & $0.46 \pm 0.46$ & $1.34 \pm 0.83$ \\
\hline & ts & $2.80 \pm 0.30$ & $1.00 \pm 0.34$ & $1.21 \pm 0.27$ & $0.74 \pm 0.45$ & $1.93 \pm 0.72$ \\
\hline
\end{tabular}

Table 3. Comparison of behavioral reactions of rats at different types of treatmentof induced $E A$, third test $(M \pm m)$. 
of behavioral responses of animals we recorded: latent period (LP), number of episodes for the first 5 minutes ( $\mathrm{n} 1)$, number of episodes for the second 5 minutes (n2), the total number of episodes for 10 minutes of observations (ns), duration of episodes for the first 5 minutes (T1), duration of episodes for the second 5 minutes (T2), the total duration of episodes (TS), the average duration of individual episodes for the first 5 minutes ( $\mathrm{t} 1$ ), the average duration of individual episodes for the second 5 minutes (t2) and the average duration of individual episodes for 10 minutes of observation (ts).

Statistical analysis of the data was carried out using computer programs Microsoft Excel 2010 and Statistica, v. 6.1. Probability of differences was evaluated using unpaired nonparametric $U$ MannWhitney. The difference between the studied parameters was considered statistically significant at a value of $p<0.05$.

\section{RESULTS AND DISCUSSION}

At the first open field test rats on the $12^{\text {th }}$ day after induction of EAE (group 1) compared to intact animals (gr.5) showed probable reduction in horizontal locomotor activity (reducing of the number of crossings peripheral squares - n1, n2, ns), vertical locomotor activity (likely reduction of latent period - LP and the trend to reduction of vertical stands- n2, ns, their duration - T2, TS and expectancy - t1, t2, ts), possible decline of research activity (increased latency period - LP and reduce of duration - Ts and the average duration of episodes of grooming - ts). Also there was observed a tendency to increase the emotional activity (increase in the duration of episodes of grooming $\mathrm{T1}, \mathrm{T} 2$, Ts at the increase of the number of grooming episodes $-\mathrm{n} 1, \mathrm{n} 2$, ns and increase of boluses) (Table. 2). Also we observed a tendency to reducing of exploratory activity.

The second open field test took place on the 15th day after EAE induction and on the $7^{\text {th }}$ day after intravenous injection of $I L-10$ to evaluate changes in behaviors of experimental animals in the course of the disease and under the influence of $I L-10$. Since significant changes in the groups of animals during the first and second test were not revealed, we do not present the results of the second test in this paper.

The third "open field" test of behavioral reactions of group 2 on the $24^{\text {th }}$ day after EAE and on the 7th day after suboccipital introduction of MSCs compared with the group 1, which did not get any treatment, revealed decrease in horizontal locomotor activity (reduction in the number of crossings of the central and peripheral squares) at significantly increased latent period - LP of the crossing of central and peripheral squares, significant increase of emotional activity (increase in duration - T2, TS and the average duration of grooming episodes - $\mathrm{t} 2$ ). There was also a tendency to reduction of vertical locomotor activity and increase of exploratory activity.

The third open field test of the rats of group 3 on the $24^{\text {th }}$ day after induction of EAE ( $15^{\text {th }}$ day after intravenous introduction of $I L-10$ and $7^{\text {th }}$ day after suboccipital introduction of $I L-10$ ) compared to the rats group 1 (table 3) noted significantly increased latency period - LP of central squares crossing at the trend to the decrease in the number of crossings of the central and peripheral squares (horizontal locomotor activity) and significant increase of vertical locomotor activity (increase in the average length of vertical stands $-\mathrm{t} 2$, ts). There were also observed changes of emotional activity (tendency to increase during the first 5 minutes and decrease in the second 5 minutes of research) and reduce of exploratory activity.

The third open field test of group 4 on the $24^{\text {th }}$ day after EAE $\left(15^{\text {th }}\right.$ day after intravenous injection of $I L-10$ and $7^{\text {th }}$ day after suboccipital injection of $I L-10$ and MSCs) compared to experimental group №1, which did not get any treatment, revealed changes in data of horizontal locomotor activity (significant increase of latent period LP of the crossing of central quadrants at a tendency to increase of the number of central and peripheral quadrants crossings) and showed a tendency to increase of vertical locomotor activity (during the second 5 minutes of the test) and exploratory activity, and also reduce of emotional activity (grooming during the first 5 minutes of the test and decrease in number of boluses) (Table 3).

The results of the study showed that induced EAE in rats leads to increase of orienting-exploratory activity with the increase of emotional stress.

There was marked a decrease in locomotor and exploratory activity and increase of emotional activity in experimental animals after induction of EAE. The probable cause of orienting and exploratory disorder of rats' behavior could be considered an increase of anxiety and fear. Revealed changes in the behavior of rats with EAE suggest significant changes in brain activity, which are due to degenerative and dystrophic changes of CNS.

Weakening of negative impact of emotional state is accompanied by increased orienting and exploratory activity. The application of MSCs and $I L-10$ has normalized the rates of cognitive activities (orientingexploratory activity) and emotional sphere (the level of fear, anxiety).

The results of our work indicate the possibility of the behavior correction of rats with EAE by treating with MSCs and $I L-10$.

\section{CONCLUSIONS}

1. The rats on the $12^{\text {th }}$ day after the induction of EAE in the open field test show changes in adaptive behavior as suppression of orienting-exploratory and activation of emotional activity.

2. On the $24^{\text {th }}$ day after EAE and on $7^{\text {th }}$ day after suboccipital introduction of MSCs in rats the open field test revealed a reduce of horizontal and vertical locomotor activity and increase of exploratory and emotional activity.

3. On the $24^{\text {th }}$ day after EAE induction (the $15^{\text {th }}$ day of the intravenous introduction of IL-10 and the $7^{\text {th }}$ day after suboccipital introduction of IL-10) in rats the open field test showed the reduction of horizontal locomotor and exploratory activity and increase of vertical locomotor and emotional activity.

4. On the $24^{\text {th }}$ day after EAE (the $15^{\text {th }}$ day of the intravenous introduction of IL-10 and the $7^{\text {th }}$ day after suboccipital introduction of IL-10 and MSCs) in rats the open field test revealed the increasing of horizontal and vertical locomotor and exploratory activity, and also reduction of emotional activity.

5. The application of MSC and IL-10 normalizes indicators of cognitive activity (orienting-exploratory activity) and emotional sphere (the level of fear, anxiety).

6. Application of MSC and IL-10 contributes to correction of adaptive behavior of experimental rats with induced EAE. 


\section{REFERENCES}

1. Augello A, Kurth T B, De Bari C. Mesenchymal stem cells: a perspective from in vitro cultures to in vivo migration and niche. Eur. Cell Mater. $2010 ; 20: 121$ - 133.

2. Bieback K, Brinkmann I. Mesenchymal stromal cells from human perinatal tissues: From biology to cell therapy. World J. Stem Cells. $2010 ; \mathbf{2}(4): 81$ - 92.

3. Wang Z, Li Y , Ahmad A, et al. Targeting miRNAs involved in cancer stem cell and EMT regulation: An emerging concept in overcoming drug resistance. Drug Resistance Updates. 2010; 13(4-5):109-118.

4. Thiery J-P, Acloque H, Huang R Y J, et al. Epithelial-Mesenchymal Transitions in Development and Disease. Cell. 2009; 139(5):871 - 890.

5. Semenova V M, Lisyany N I, Stayno L P. Proliferativnyj i differencirovochnyj potencial mezenhimal'nyh stvolovyh kletok iz zhirovoj tkani v uslovijah kul'tivirovanija [Proliferative and differentiation potential of mesenchymal stem cells from adipose tissue in culture conditions]. Ukraïns'kij nejrohirurgichnij zhurnal - Ukrainian Journal of Neurosurgical, 2014; 3:24 - 29.

6. Kalluri J. EMT: When epithelial cells decide to become mesenchymal-like cells. J. Clin. Invest. 2009; 119(6):1417 - 1419.

7. Selezneva T, Mishyn A, Barsukow V. Gistologiya: polnyi kurs za tri dnya [Histology: A full course of 3 days]. Moscow, Eksmo, 2007. 354 p. In Russian.

8. Kalluri R, Zeisberg M. Fibroblasts in cancer. Nat. Rev. Cancer. 2006; 6(5):392 - 401.

9. Patel A, Park E, Kuzman M, et al. Multipotent Menstrual Blood Stromal Stem Cells: Isolation, Characterization, and Differentiation. Cell Transplantation. 2008; 17(3):303 $-311$.

10. Huang GT-J, Gronthos S, Shi S. Mesenchymal Stem Cells Derived from Dental Tissues vs. Those from Other Sources: Their Biology and Role in Regenerative Medicine. JDR. 2009; 88(9):792 - 806.

11. Taghizadeh RR, Cetrulo KJ, Cetrulo CL. Wharton's Jelly stem cells: Future clinical applications. Placenta. 2011; 32(4):311 - 315.

12. Maslova 00, Shuvalova NS, Sukhorada OM, et al. Heterogeneity of Umbilical Cords as a Source for MSC. Dataset Papers in Biology. 2013; Article ID 370103, http://dx.doi.org/10.7167/2013/370103.

13. Tang YL, Zhang YC, Qian K, et al. Improved Graft Mesenchymal Stem Cell Survival in Ischemic Heart With a Hypoxia-Regulated Heme Oxygenase-1 Vector. J. Am. Coll.Cardiol. 2005; 46(7):1339-1350.

14. Lalani I, Bhol K, Ahmed AR. Interleukin-10: biology, role in inflammation and autoimmunity. Ann. Allergy. 1997; 79:469-483.

15. Zhang $X$, Koldzic DN, Izikson L, et al. IL-10 is involved in the suppression of experimental autoimmune encephalomyelitis by CD25+CD4+ regulatory $\mathrm{T}^{+}$-cells. Int. Immunol. 2004; 16(2):249-256.

16. Segal BM, Dwyer BK, Shevach EM. An Interleukin (IL)-10/IL-12 Immunoregulatory Circuit Controls Susceptibility to Autoimmune Disease. J. Exp. Med. 1998; 187(4):537-546.

17. Bettelli E, Das MP, Howard ED, et al. IL-10 Is Critical in the Regulation of Autoimmune Encephalomyelitis as Demonstrated by Studies of IL-10-and IL-4-Deficient and Transgenic Mice.J. Immunol. 1998; 161:3299-3306.

18. European convention for the protection of vertebrate animals used for experimental and other scientific purposes. Council of European. Strasbourg, 1986. $51 \mathrm{p}$.

19. Zakon Ukrainy «Pro zahyst tvaryn vid zhorstokogo povodzhennja» vid 21.02.2006 №3447-IV [Law of Ukraine «On the Protection of Cruelty to Animals» from 21.02.2006 №3447-IV]. Vidomosti Verhovnoi’ Rady Ukrai’ny - Bulletin of Verkhovna Rada of Ukraine, 2006; 27:990. In Ukrainian.

20. Markov DA. Demielinizirujushhie zabolevanija nervnoj sistemy v jeksperimente i klinike [Demyelinating diseases of the nervous system in experimental and clinical]. Minsk: Nauka i tehnika - Minsk: Science and Technology, 1975; 360 p. In Russian.

21. Tsymbaliuk VI. Osoblyvosti modeljuvannja ta perebigu eksperymental'nogo alergichnogo encefalomijelitu [Features and flow modeling of experimental allergic encephalomyelitis]. Ukr. nejrohirurgichnyj zhurnal - Ukrainian Journal of Neurosurgical, 2005; 1:12-14. In Ukranian.

22. Kasyanenko YuA. Vplyv suspenzii' klityn fetal'nogo mozku na perebig eksperymental'nogo alergichnogo encefalomijelitu : avtoref. dys. na zdobuttja nauk. stupenja kand. med. nauk: spec. 14.01.05. «Nejrohirurgija» [The impact of fetal brain cell suspension in the course of experimental allergic encephalomyelitis: abstract thesis]. Kyiv - Kyiv, 2006. 20 p. In Ukranian.

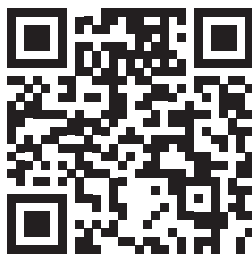

The authors indicate no potential conflicts of interest. 